\begin{tabular}{ll}
\hline 臨 & 床 \\
\hline
\end{tabular}

聴神経腫瘍に対する T2 強調像の有用性



\title{
The Usefulness of High-Resolution T2-Weighted MR Imaging for the Detection of Acoustic Neurinoma
}

\author{
Koshi Ikeda, Akihiko Nakamura, Masahiko Izumikawa, Sang Kil Ha-Kawa, \\ Hiroaki Kurokawa, Kyosuke Uokawa, Yoshihisa Nakano, Yoshimasa Tanaka, \\ Koichi Tomoda and Toshio Yamashita \\ (Kansai Medical University)
}

\begin{abstract}
Unenhanced high-resolution T2-weighted fast spin echo MR imaging was compared with enhanced T1-weighted spin echo MR imaging in the detection of acoustic neurinoma.

A total of 47 patients with pathologically documented acoustic neurinoma were reviewed, 20 of which underwent high-resolution T2-weighted imaging of the cerebellopontine angle, internal auditory canal region.

The size of the acoustic neurinomas ranged from 4 to $50 \mathrm{~mm}$ in maximum diameter. The mean maximum diameter was $17 \mathrm{~mm}$, and 6 neoplasms were less than $10 \mathrm{~mm}$ in diameter. Nineteen of 20 masses were clearly identified on $\mathrm{T} 2$-weighted images. However, small abnormalities on enhanced T1-weighted images corresponded to a hypointense focus on T2-weighted images. All 20 masses were hypointense relative to cerebrospinal fluid on $\mathrm{T} 2$-weighted images.

High-resolution T2-weighted imaging may be considered an adequate method of examination for the evaluation of possible acoustic neurinoma.
\end{abstract}

Key words : high resolution T2-weighted imaging, MRI, acoustic neurinoma

$$
\text { はじめに }
$$

聴神経腫瘍は小脳橋角部の腫瘍としては最も多く, そ の症状は一側性の感音性難聴・耳鳴・めまい等多彩であ り, 診断は容易ではない。さらに聴性脳幹反応 (ABR) 等の神経耳科学的検査もスクリーニングとして有用であ るが，その確定診断にお打る画像診断の役割は大きい。 画像診断には磁気共鳴画像 (MRI) が現在最も使用され
ている.いくつかの MRI の撮像法のらちで, 造影剂投 与後の $\mathrm{T} 1$ 強調像が小脳橋角部拉よび内耳道の聴神経腫 瘍のスクリーニングとして用いられ, 高い診断能が報告 されている1). T2 強調像では内耳道内の聴神経は脳资 䯣夜上り低信号で水平断像で 2 本の線状影としてみられ， 腫瘤は低信号の小結節として認められる2).しかし従来 の T2 強調像は撮像時間が長いため分解能を上げること 
が困難であった，最近の撮像技術の進歩により fast spin echo 法が考案され，分解能が高いT2 強調像が短時間 で得られるようになっだ3。造影剤を使用しない撮像法 のみで病変検出ができれば，撮像時間が短縮され高額な 造影剤の費用を節約でき，望ましいスクリーニング検査 となる. fast spin echo 法を用いた高分解能 T2 強調像 での聴神経腫瘍の診断についての報告は散見される4) 6) が，臨床診断のみで手術や組織診断を得ていない対象も 含まれ，T2強調像の聴神経腫瘍診断に扝ける有用性に ついていまだ充分な結論は得られていない，今回我々は 聴神経腫瘍手術症例を対象に高分解能 T2 強調像と造影 $\mathrm{T} 1$ 強調像とを比較検討した。

\section{方法}

1990年から1996年 7 年間で関西医科大学病院に执いて 手術的加療を施行し, 病理組織学的検討を行った聴神経 腫瘍 47 症例の 5 ち高分解能 $\mathrm{T} 2$ 強調像を撮像し得た 20 例 を検討の対象とした。対照として T1 強調像で陽性所見 がみられなかった79例を用いた。

使用された MRI 装置は東芝社製 MRT-FX III と GE 横河社製 Sierraで, いずれも1.5テスラの高磁場装置で ある。撮像法は T2 強調像は 2D fast spin echo 法で 4000/100/2(繰り返し時間 $[\mathrm{ms}] /$ エコー時間 $[\mathrm{ms}] /$ 加算 回数)を用い、エコートレインは 9 である. スライス厚 は $4 \mathrm{~mm}$ ，マトリックスは $256 \times 160$, FOV (field of view) は $15 \mathrm{~cm}$ であった。撮像時間は約 4 分 48 秒である。 T1 強調像はspin echo 法で 400/20/2を用い，スライス 厚は $3.5 \mathrm{~mm}$ ，マトリックスは $256 \times 192, \mathrm{FOV} は 15 \mathrm{~cm}$ で撮像時間は約 5 分 7 秒であった。 $0.1 \mathrm{mmol} / \mathrm{kg}$ の Gd-DTPA (gadopentetate dimeglumine) 静注前之直後 に $\mathrm{T} 1$ 強調像を撮像した。また $\mathrm{QD}$ 型頭部コイルを用い た.

\section{結 果}

20例の腫瘍の大ささは T2 強調像で測定し， $4 \mathrm{~mm}$ か ら $50 \mathrm{~mm}$ (平均 $17 \mathrm{~mm}$ ) であった。 6 例は $10 \mathrm{~mm}$ 以下 で内耳道内に限局していた。

高分解能 T2 強調像で聴神経䩗腫は20例中19例 (95\%) に描出でき, 造影後 T1 強調像は全例で認められた(表). 対側の正常部には高分解能 T2 強調像で偽陽性例はみら れなかった。 T1 強調像で陽性所見がみられなかった79 例では，T2 強調像で陽性である偽陽性例は存在しなか
表 手術施行例の MRI 所見

\begin{tabular}{|c|c|c|c|c|c|}
\hline 年齢 & 性別 & 病側 & $\begin{array}{l}\begin{array}{c}\text { 大きざ } \\
(\mathrm{mm})\end{array} \\
\end{array}$ & $\begin{array}{l}\text { 造影 } \\
\mathrm{T} 1 \text { 強調像 }\end{array}$ & $\mathrm{T} 2$ 強調像 \\
\hline 54 & 女 & 左 & 4 & 陽性 & 陰性 \\
\hline 34 & 女 & 右 & 6 & 陽性 & 陽性 \\
\hline 35 & 男 & 左 & 8 & 陽性 & 陽性 \\
\hline 60 & 女 & 左 & 10 & 陽性 & 陽性 \\
\hline 51 & 男 & 右 & 10 & 陽性 & 陽性 \\
\hline 59 & 女 & 右 & 10 & 陽性 & 陽性 \\
\hline 38 & 男 & 左 & 15 & 陽性 & 陽性 \\
\hline 72 & 女 & 右 & 15 & 陽性 & 陽性 \\
\hline 55 & 女 & 右 & 15 & 陽性 & 陽性 \\
\hline 53 & 男 & 左 & 15 & 陽性 & 陽性 \\
\hline 44 & 女 & 右 & 15 & 陽性 & 陽珄 \\
\hline 46 & 女 & 左 & 17 & 陽性 & 陽性 \\
\hline 69 & 女 & 右 & 20 & 陽性 & 陽性 \\
\hline 58 & 女 & 右 & 20 & 陽性 & 陽性 \\
\hline 56 & 女 & 右 & 20 & 陽性 & 陽性 \\
\hline 61 & 女 & 右 & 20 & 陽性 & 陽性 \\
\hline 30 & 女 & 左 & 20 & 陽性 & 陽性 \\
\hline 43 & 女 & 左 & 30 & 陽性 & 陽性 \\
\hline 29 & 女 & 右 & 40 & 陽性 & 陽性 \\
\hline 25 & 男 & 右 & 50 & 陽性 & 陽性 \\
\hline
\end{tabular}

った。内耳道では上下前庭神経, 蝸牛神経, 顔面神経は 高分解能 $\mathrm{T} 2$ 強調水平断像で脳幹部より連続する 2 本の 線状影としてみられた(図 1 )。高分解能 T2 強調像で描 出された $10 \mathrm{~mm}$ の聴神経腫瘍を図 2 に示す. $4 \mathrm{~mm}$ の 1 症例が高分解能 T2 強調像で描出し得なかった。この 1 症例屯造影後 $\mathrm{T} 1$ 強調像と対比すれば $\mathrm{T} 2$ 強調像で低

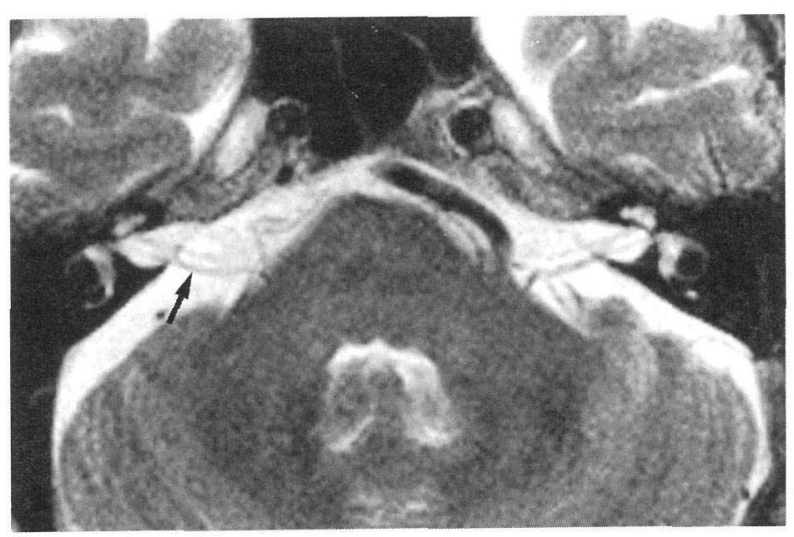

図 1 高分解能 T2 強調像 内耳道の神経構造は脳幹部より連続する 2 本の線状影 (矢印)として描出される. 


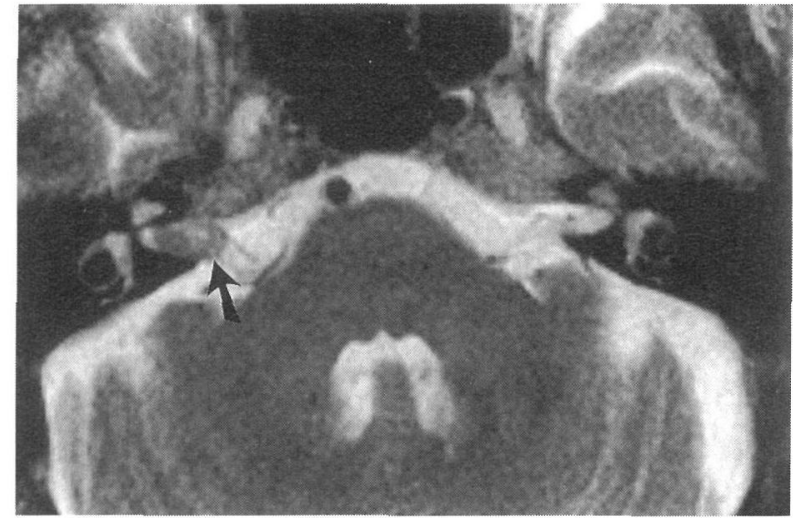

A

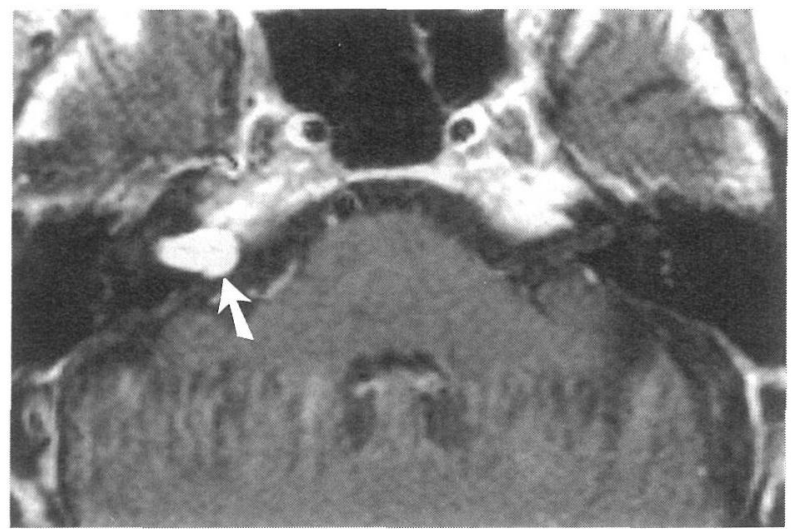

B

図 2 典型的な内耳道に限局する右聴神経腫瘍 (矢印) A. 高分解能 $\mathrm{T} 2$ 強調像. B. 造影 $\mathrm{T} 1$ 強調像.

信号域として確認できた（図３）.

考察

通常の spin echo 法による T2 強調像では微細構造を 描出するのに充分な分解能を得るためには撮像時間が長 くなり実用的ではない, gradient echo法を用いること で撮像時間を短縮し高分解能画像を得る試みがみられ る7)が，側頭骨は種々の組織が混在して扣り susceptibility (磁化率) の効果が強く又られ, 微細構造を描出 するには不利である。一方, fast spin echo 法では, 1 回の励起パルス当たりにデータ収集を複数回行うことで 撮像時間を短縮でさる。たと方ばエコートレインが 9 回 得られれば，撮像時間が $1 / 9$ となる3)。乙かし自験例の よらな $2 \mathrm{D}$ 法では $4 \mathrm{~mm}$ と比較的厚いスライス厚を用い

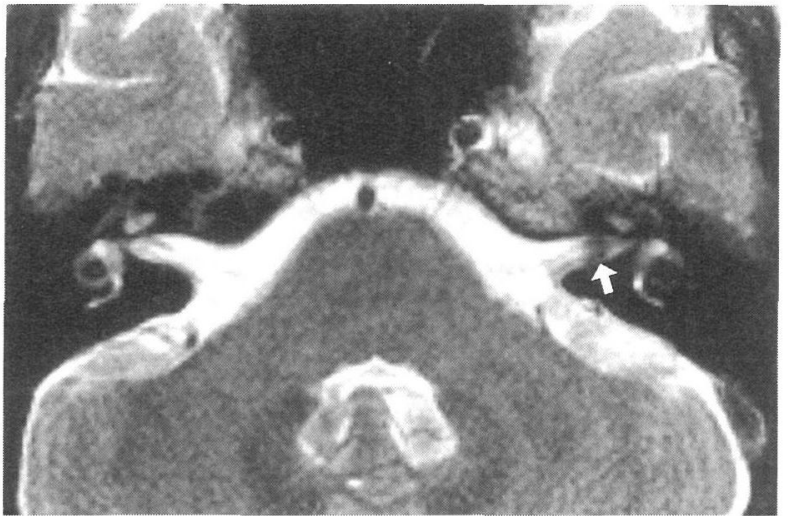

A

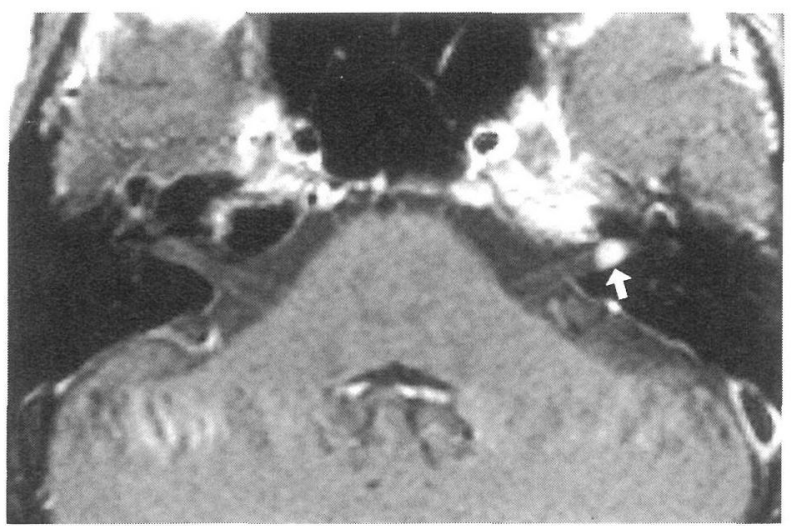

B

図 3 左聴神経腫痬 (矢印)

A. 高分解能 T2 強調像偽陰性. B. 造影 T1 強調像.

ているため, partial volume effect が原因で画像が劣化 する. 3 次元フーリエ変換法を用いてデータ収集を行ら $3 \mathrm{D}$ 法により $1 \mathrm{~mm}$ 近い薄いスライス厚が可能である ${ }^{8) 9}$ が，撮像時間が15分以上と長くなり体動による motion artifact や资䯣液の flow により画像が劣化する可能性が ある。これまでの高分解能 T2 強調像による聴神経腫瘍 描出の報告では経過観察中の症例が含まれている場合が 多(2)6)が，自験例ではすべて手術にて確認されている 症例を対象に検討を行って扣り意義深いと思われる。

正常内耳道を走行する上下前庭神経, 螖牛神経, 顔面 神経は， $\mathrm{T} 2$ 強調水平断像では脳脊髄液より低信号の 2 本の線状影としてみられ，聴神経腫瘍は低信号の小結節 像として認められる2)。聴神経腫瘍は高信号であるので $\mathrm{T} 2$ 強調像で脳猆髄液と紛らわしいとする報告がある2)10) 
が, fast spin echo 法で繰り返し時間を $4000 \mathrm{msec}$ 以上 に，エコー時間を $100 \mathrm{msec}$ 以上にすれば脳脊髄夜は充 分高信号になる4)11)。我々も聴神経腫瘍と脳脊㖪液の間 で充分コントラストを得ることができ診断可能であった。

覀性度の高い耳下腺腫瘍は細胞分布が密で $\mathrm{T} 2$ 強調像 で低信号を呈する1213)。同様に小さな聴神経腫瘍は細胞 分布が密である14)ので, T2 強調像で低信号を呈し脳资 䯣液と明瞭なコントラストを示す．比較的大きな聴神経 腫瘍は囊胞成分を含み $\mathrm{T} 2$ 強調像で著しい高信号の部分 を混じ，辺縁が不明瞭になる場合がある．しかし腫瘍が 比較的大きいため，その存在診断は容易であり問題とは ならない。

今回の検討から, 聴神経腫瘍のスクリーニングとして はまず T2 強調像を撮像することによって異常例の拾い 上げは可能であると考兄られた． T2 強調像のみでスク リーニングを行らと, 脂肪の存在により高信号となる類 上皮腫や脂肪腫の診断が困難となり，メトへモグロビン に変化することで高信号となる出血も確認できなくなる 可能性を避けるために, T1 強調像もあわせて撮像する ことが望ましい。

高分解能 $\mathrm{T} 2$ 強調像は造影後 $\mathrm{T} 1$ 強調像とほぼ同等の 正診率である. 通常のスクリーニングには高分解能 T2 強調像を用い，小結節像や聴神経の肥厚像と鑑別が難し い症例は造影剂を使用し $\mathrm{T} 1$ 強調像を追加すればよいと 思われる. $4 \mathrm{~mm}$ の腫瘍は指摘し得なかったが, 腫瘍は 低信号域として描出されていた. 注意深い読影により, 存在が否定できない境界例とみなすことによって, 造影 後 $\mathrm{T} 1$ 強調像を行うことで正しい診断を得ることができ るものと考吕れる.

3D fast spin echo 法の欠点である長い撮像時間を改善 するため, 最近 200 以上のエコートレインが得られ, ハー フ・フーリエ法を併用することで短時間で撮像する方法 (FASE, HASTE) が報告されている15). また高感度の受 信コイルである phased-array coil による内耳道描出の 試みが報告されている5)15). T2 強調像の分解能の改善は 現在も進んで扣りさらに内耳道の小腫瘤の描出能は改善 されると思われる.今後高価な造影剂を使用せず短時間 で聴神経腫瘍のスクリーニングを行うことが可能である と思われる.

\section{まとめ}

1 ) 手術的加療を施行した聴神経腫瘍 47 例中, 2D fast spin echo 法を用いた高分解能 T2 強調像を撮像し 得た 20 例に执いて, 造影後 $\mathrm{T} 1$ 強調像之比較検討した.

2 ) 聴神経腫瘍症例 20 例中19症例で高分解能 T2 強調 像によって描出できた. 残り 1 例に沶いても造影後 T1 強調像と比較すれば，低信号部としてみられた．

3 ）今後高分解能 $\mathrm{T} 2$ 強調像による聴神経腫瘍のスク リーニングが可能と考兄られるが，鑑別が難しい場合に は造影 $\mathrm{T} 1$ 強調像を追加する必要がある。

\section{謝辞}

本研究の一部は文部省科学研究費補助金基盤研究 (A) (1) 課 題番号08307013によって行われた.ここに記して深謝する.

\section{参考文献}

1) Curati W, Graif M, Kingsley DPE, et al : Acoustic neurinomas; Gd-DTPA enhancement in MR imaging. Radiology 158 : 447 451, 1986.

2) Enzmann D and O'Donohue J : Optimizing MR imaging for detecting small tumors in the cerebellopontine angle and internal auditory canal. Am J Neuroradiol $8: 99 \sim 106$, 1987.

3) Hennig J, Nauerth A and Friedburg H : RARE imaging; a fast imaging method for clinical MR. Magn Reson Med 3: : 823 833, 1986.

4) Phelps P : Fast spin echo MRI in otology. J Laryngol Otol $108: 383 \sim 394,1994$.

5) Allen RW, Harnsberger HR, Shelton C, et al : Low-cost high-resolution fast spin-echo MR of acoustic schwannoma; an alternative to enhanced conventional spin-echo MR? Am J Neuroradiol $17:$ 1205 1210, 1996.

6) Fukui MB, Weissman JL, Curtin HD, et al : T2-weighted MR characteristics of internal auditory canal masses. Am J Neuroradiol $17:$ 1211 1218, 1996.

7 ) Casselman JW, Kuhweide R, Deimling M, et al : Constructive interference in steady state; 3DFT MR imaging of the inner ear and cerebellopontine angle. Am J Neuroradiol $14: 47 \sim 57,1993$.

8 ) Rand SD, Heiserman J, Drayer B, et al : MR cisternography of the cerebellopontine angle with a high resolution T2W 3D fast spin echo technique. Proceedings of 33 rd Annual Meeting of the American Society of Neuroradiology. pp 163 164, Chicago, 1995.

9 ) Naganawa S, Fukatsu H, Ishigaki T, et al : MR cisternography of the cerebellopontine angle with a $3 \mathrm{D}$ fast $\mathrm{SE}$ sequence. Radiology 201(P) : 450, 1996.

10) Lhuillier F, Doyon D, Halimi $P$, et al : Magnetic resonance 
imaging of acoustic neuromas; pitfalls and differential diagnosis. Neuroradiology $34: 144 \sim 149,1992$.

11) Renowden $S$ and Anslow $P$ : The effective use of magnetic resonance imaging in the diagnosis of acoustic neurinomas. Clin Radiol 48 : 25 28, 1993.

12) Som PM and Biller HF : High grade malignancies of parotid gland; identification with MR imaging. Radiology $173: 823 \sim 826,1989$.

13）朝子幹也, 岩井大, 池田耕士, 他 : 耳下腺悪性腫瘍の MRI -T2 強調画像と病理組織像一. 口咽科 $8: 383 \sim 389$, 1996.
14) Kasantikul V, Netsky M, Glasscock M, et al : Acoustic neurilemmoma ; clinicoanatomic study of 103 patients. J Neurosurg $52: 28 \sim 35,1980$.

15）長縄慎二, 深津 博, 石垣武男, 他 : 3D-FASE と QD surface phased array coil による内耳道高分解能撮影. 日磁医 誌 16S : 227, 1996.

$\left(\begin{array}{l}\text { 原稿受付 : 平成 } 9 \text { 年 } 1 \text { 月 } 27 \text { 日 } \\ \text { 原稿採択 : 平成 } 9 \text { 年 } 2 \text { 月 } 26 \text { 日 } \\ \text { 別刷請求先 : 池田耕士 } \\ \text { †570 守口市文園町 } 10-15 \\ \text { 関西医科大学放射線科学教室 }\end{array}\right)$ 